\title{
AYO TANAMKAN JIWA KEWIRAUSAHAAN DALAM DIRI KITA
}

\author{
Namira Eka Fibriani \\ Program Studi Pendidikan Guru Sekolah Dasar \\ Fakultas Keguruan dan IImu Pendidikan \\ Universitas Nahdlatul Ulama Sidoarjo \\ Email : namirafibriani11@gmail.com
}

\section{Pengantar}

Mas'ud Machfoedz dan Mahmud Machfoedz (2004) menjelaskan bahwa wirausaha adalah seorang inovator yang mampu mengubah kesempatan menjadi sebuah ide yang bisa di jual, dapat memberikan nilai tambah melalui upaya, waktu, biaya, serta kecakapan dengan tujuan mendapatkan keuntungan.

Di era globalisasi ekonomi saat ini mau tidak mau harus dirasakan oleh setiap negara. Sehingga menyebabkan perekonomian suatu negara bergantung kepada negara lainnya. Dari hal tersebut kita harus pandai-pandai dalam menyesuaikan pribadi dengan peradaban zaman. Di tanah air kita tingkat pengangguran dalam kondisi sangat tinggi, dengan hal ini akan berdampak pada pertumbuhan ekonomi di Indonesia.

Pada hakikatnya setiap orang sudah tertanam apa yang dinamakan jiwa wirausaha yang berarti memiliki kreativitas dan tujuan tertentu, serta berusaha untuk mencapai keberhasilan dalam hidupnya. Namun seringkali kita jumpai bahwa daya cipta apa yang dimiliki orang-orang kurang diterapkannya, kalaupun diterapkan tapi masih kurang mampu untuk menjual maupun menumbuhkan daya tarik bagi masyarakat. Zaman globalisasi ini kita semua harus mampu mempunyai kemampuan dalam segala bidang. Maka dari itu penting sekali dengan adanya pembekalan kewirausahaan. Di zaman sekarang ini nampaknya mulai menjamur pengusaha muda dari berbagai jenis bisnis. Hal ini merupakan perubahan yang cukup besar untuk mengatasi pengangguran di Indonesia. Jika bisa dilakukan mulai sekarang mengapa harus menunggu nanti.

Modal utama menjadi wirausaha adalah motivasi yang kuat dari dalam diri individu dan mempunyai keberanian dalam mengambil resiko. Joko Widodo (2015) menjelaskan bahwa menjadi wirausaha juga mesti berani berpikir out of the box dan berani keluar dari zona nyaman. Biasanya kalau terlalu nyaman, takut ambil resiko.

\section{Cara menanamkan jiwa wirausaha}

Apakah bisa kita memulai usaha tanpa bekal pendidikan tertentu? Jawabannya tentu bisa. Mengapa? Karena saat kita memulai untuk berwirausaha kita harus mempunyai jiwa kewirausahaan. Dengan jiwa wirausaha kita bisa merintis bisnis-bisnis yang akan kita jalani. 


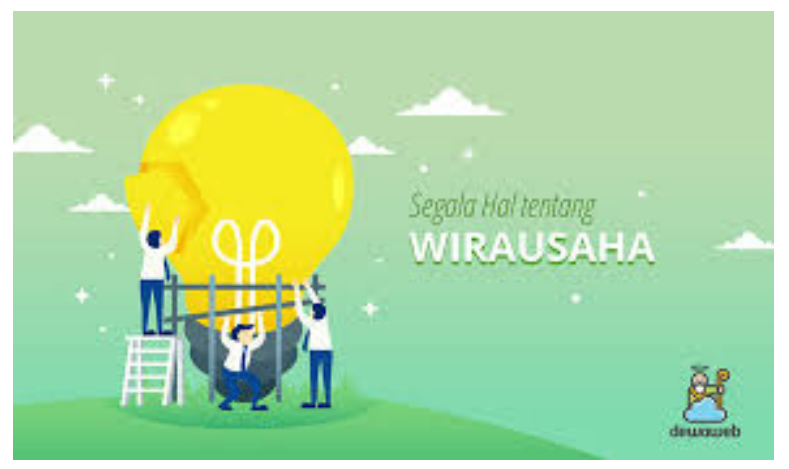

gambar 1. Wirausaha: panduan dasar lengkap (https://www.dewaweb.com/blog/wirausaha-panduandasar/, 2018)

Adapun cara menanamkan jiwa wirausaha sebagai berikut :

1. Kuatkan tekad dan niat. Hal ini merupakan cara pertama dalam menumbuhkan jiwa wirausaha. Dengan kita menguatkan tekad dan niat, nantinya kita akan siap menghadapi segala rintangan dan cobaan yang pasti akan kita dapatkan selama merintis bisnis.

2. Buat target dan rencana masa depan. Dengan adanya target dan rencana kita akan lebih siap membangun usaha, kita juga akan lebih mudah membuat langkah-langkah kerja yang harus dijalani. Dengan hal ini kita akan lebih termotivasi untuk memajukan bisnis kita

3. Miliki ide bisnis. Kita harus mengasah ide-ide untuk mendirikan bisnis. Kita tidak akan menjadi wirausahawan jika tidak memiliki ide. Tidak perlu melangkah jauh untuk melakukannya, cukup kamu mulai dengan hobi dan minat bakat kamu. Dengan itu kamu akan menjalankan bisnis dengan rasa yang sangat menyenangkan.

4. Menumbuhkan rasa optimis. Dengan ini kamu harus persiapkan mentalmu untuk menghadapi rintangan saat merintis bisnismu. Karena dengan adanya rasa optimis kita tidak akan mudah untuk menyerah dan mempunyai rasa ingin melanjutkan bisnis.

5. Harus fokus. Jika diawal kita sudah punya target dan rencana bisnis maka kita harus fokus terhadap apa yang kita rencanakan. Jangan mudah kamu melirik bisnis tetanggamu bisa jadi bisnis yang awalnya kamu bentuk bisa kacau begitu saja.

6. Menumbuhkan rasa keberanian. Saat kamu sudah mempunyai tekad untuk terjun di dunia wirausaha kamu juga harus siap dengan segala tantangan. Maka dari itu kamu hatus mempunyai keberanian. Jangan mudah takut terhadap tantangan dan jangan mudah menyerah. 
7. Melatih kepekaan terhadap peluang bisnis. Jika kamunsudah fokus terhadap bisnismu kamu juga harus mau menerima kritik dan saran dari orang lain. Jangan jadikan hal itu sebagai ejekan melainkan masukan.

\section{Memulai usaha}

Salah satu hal yang harus diketauhi sebelem memulai usaha yakni aspek penting bagi seorang pengusaha. Situs WWW.wirausaha.com (yang dirilis pada tanggal 21 November 2007) memberitakan bahwa dalam salah satu seminar, Gerald Abrahamsalah seorang penasihat bisnis pada sebuah firma hukum mengungkapkan bahwa terdapat Sembilan aspek penting sebelum memulai usaha, yaitu:

1. Memahami konsep produk

2. Membuat visi dan misi bisnis

3. Perlunya winning, positive dan learning attitude untuk menjadi sukses

4. Membuat peencanaan dan strategi bisnis

5. Pengetahuan dasarr manajemen

6. Optimalisasi sumber daya manusia

7. Kreativitas, kepemiminan

8. Pengetahuan dasar pengelolaan keuangan

9. Pemasaran, pelayanan

\section{Keuntungan berwirausaha}

Ternyata ada juga lo keuntungan dari berwirausaha :

1. Kamu memiliki kesempatan membuka wirausaha sendiri disaat terbatasnya lowongan pekerjaan

2. Dengan adanya berwirausaha kamu akan mendapatkan apa yang kamu tanam sebanding apa yang kamu petik. Maksudnya kamu akan mendaptkan penghasilan setara dengan kerja kerasmu. Beda halnya di perusahaan, terkadang apa yang kita kerjakan tidak sesuai dengan ekspetasi

3. Bebas, dalam artian kamu punya kewenangan dalam cara mengatur cara kerjamu. Jadi kita tidak perlu kerja dari pagi sampai sore, semua tergantung pada diri kita 
sendiri.

4. Mengembangkan kreativitas dan inovatif. Karena kondisi selera pasar itu bergerak secara fluktuatif. Dengan adanya kondisi tersebut kita mendorong diri untuk mengembangkan ide-ide baru lalu memperbaiki kinerja usaha .

\section{Penutup}

Di zaman sekarang ini nampaknya mulai menjamur pengusaha muda dari berbagai jenis bisnis. Hal ini merupakan perubahan yang cukup besar untuk mengatasi pengangguran di Indonesia. Dengan segala kesempatan yang masih kaian miliki, kalian harus berani untuk memulai berwirausaha. Dalam berwirausaha kita harus mengetahui cara dan aspek penting dalam berwirausaha. Jika kalian ingin berwirausaha bagaimanapun, mental yang siap aakan lebih memungkinkan untuk membangun usaha yang maju. Jika hari ini bisa ditaklukkan mengapa harus menunggu besok. 


\section{Reference}

Priansa, Donni Juni. (2010). Menumbuhkan Jiwa Entrepreneur Dalam Diri Siswa. Bandung : PT Setia Purna.

Suryana Yuyus dan Bayu Kartib. (2011). Kewirausahaan Pendekatan Karakteristik Wirausahawan Sukses. Jakarta : Kencana.

Yasha. (2018). Wirausaha: Panduan Dasar Lengkap diakses pada 31 Oktober 2018 https://www.dewaweb.com/blog/wirausaha-panduan-dasar/

https://www.google.com/url/?q=https://edukasi.kompas.com/read/2018/03/23/08450 051/apa-jadinya-indonesia-tanpa-wirausaha-\&usg=AOvVaw2fdi952T_RjotvVpdzZTga diakses pada tanggal 23 Maret 2018

http://jabar.tribunnews.com/2017/09/11/ini-lho-keuntungan-jika-kamu-punyawirausaha-sejak-dini-berikut-komentar-sobat-milenial-jabar?page $=4$ diakses pada tanggal 11 September 2017

https://dosenpsikologi.com/tips-menumbuhkan-jiwa-wirausaha diakses pada tanggal 29 Desember 2017

Purnomo,A.(2017,December

5). Pengertian

Edupreneur.

http://doi.org/10.17605/OSF.IO/J3BCR

Setyawati,I.,Purnomo,A.,Irawan,D.E.,Tamyiz,M.,\&Sutiksno,D.U.(2018).A Visual Trend of Literature on Ecopreneurship Research Overviewed within The Last Two Decades. Journal of Entrepreneurship Education, 21(4), 1-7.

Purnomo,A.(2018,December 19).Industri 4.0 untuk Wirausaha Jaman Now. http://doi.org/10.17605/OSF.IO/TU7B5 